\title{
Marble Powder Blended Utilization Polyurethane as Soundproof Materials
}

\author{
Yusrizal $^{\mathrm{a}, 1,{ }^{*}}$, Muhammad Ali ${ }^{\mathrm{b}, 2}$, Nuzuli Fitriadi ${ }^{\mathrm{c}, 3}$, Irwansyah Syam ${ }^{\mathrm{d}, 4}$, Balkhaya ${ }^{\mathrm{e}, 5}$, Hardi Susanto ${ }^{\mathrm{f}, 6}$ \\ ${ }^{1-5}$ Department of Mechanical Engineering South Aceh Polytechnic, Tapaktuan, Indonesia \\ ${ }^{6}$ Department of Mechanical Engineering, Teuku Umar University, Meulaboh, Indonesia \\ 1yoosjal@gmail.com*; 2 muhammadali@gmail.com, ${ }^{3}$ nuzuli.fitriadi@gmail.com, \\ ${ }^{4}$ rasyadoank.id@gmail.com, ${ }^{5}$ balkhaya@gmail.com, ${ }^{6}$ hardi.susanto@gmail.com.
}

\begin{tabular}{ll} 
ARTICLE INFO \\
\hline Article history: \\
Accepted
\end{tabular}

Keywords

Marble powder

Polyurethane

Impedance tube

Acoustic

Frequency

\section{ABSTRACT}

As technology advances, the development of equipment used by humans increases, and most of the equipment produces unwanted sounds that cause noise. An alternative material for soundproofing is needed, which is relatively cheap and readily available in the community by using marble powder as a polyurethane mixture in soundproof panels. This study aimed to determine the effect of the sound absorption coefficient value and determine the relationship between the frequency of the sound source and the sound absorption coefficient of acoustic materials using marble powder mixed with polyurethane in different compositions. The sound absorption test in this study was carried out using a two-microphone impedance tube and has a frequency limit of $125 \mathrm{~Hz}-4000 \mathrm{~Hz}$, variations in the mass composition of marble and polyurethane powder $1: 1,1: 2$, and $1: 3$ with a thickness of $5 \mathrm{~cm}, 3 \mathrm{~cm}$, and $1 \mathrm{~cm}$. Then the test results of the $1: 1$ test specimen, the lowest sound absorption coefficient value was obtained $0.100 .73 \mathrm{~cm}-1$ at a thickness of $1 \mathrm{~cm}$ with a frequency of $4000 \mathrm{~Hz}$, and the highest was $0.73 \mathrm{~cm}-1$ at a thickness of $5 \mathrm{~cm}$ with a frequency of $125 \mathrm{~Hz}$, the test results 1: 2 test specimen, the lowest sound absorption coefficient value is $0.29 \mathrm{~cm}-1$ at a thickness of $5 \mathrm{~cm}$ at a frequency of $4000 \mathrm{~Hz}$, and the highest is $0.67 \mathrm{~cm}-1$ at a thickness of $5 \mathrm{~cm}$ at $250 \mathrm{~Hz}$, then the test results of the test specimen are 1: 3 values The lowest sound absorption coefficient was 0.24 at a thickness of $1 \mathrm{~cm}$ at a frequency of $4000 \mathrm{~Hz}$ and the highest was 0.71 at a thickness of $5 \mathrm{~cm}$ at a frequency of $250 \mathrm{~Hz}$. For the comparison of the sound absorption coefficient values based on the composition and consistency, the lowest and highest sound absorption coefficient values are found in 1:1 specimens with a thickness of $1 \mathrm{~cm}$ and $5 \mathrm{~cm}$ with the best sound absorption coefficient values on average at a frequency of $500 \mathrm{~Hz}$, but in material 1:2 and 1:3 obtained the sound absorption coefficient values are in between because the thicker the material, the higher the sound absorption coefficient value. Thus it can be concluded that the polyurethane composite material mixed with marble powder can be used as a sound-absorbing panel material, especially in a 1: 1 composition.

Copyright (C) 2021 Politeknik Aceh Selatan. All rights reserved.

\section{Introduction}

South Aceh Regency has various potential natural resources, one of which is a marble. Marble is a natural stone product that is widely used in everyday life. In cutting marble, there is a lot of marble powder as a by-product that has not been maximally utilized. This powder can be converted into valuable goods by turning these by-products into goods of economic value. Several studies have been carried out in the use of marble powder, such as mineral analysis [1], testing the characteristics of marble powder composite material [2], making light bricks [3], and marble powder as raw materials 
for making houses [4]. With the advancement of technology, the development of equipment used by humans has increased. Most of these devices produce undesirable noises that can create noise. The various types of sound-absorbing materials such as polyurethane were developed [5] [6]. So far, the materials used as noise absorbers are made of synthetic materials, which are quite expensive. Therefore we need alternative materials for silencers that are relatively cheap and easily available in the community [7]. Polyurethane is a solid plastic foam mixture of Polyol and Isocyanate solutions, which is commonly used as a heat-insulating material for storage. Solid polyurethane foam is one of the most efficient, high-performance insulating materials, allowing for very good energy savings in adjusting space usage. Excellent insulation of buildings is a significant contributor [8].

\section{Methode}

In researching the utilization of marble powder as a polyurethane mixture on soundproof panels. Based on the method of implementation, the stages carried out are as follows:

1. They are preparing research tools and materials by preparing acoustic wall molding tools, marble powder, and polyurethane.

2. Making acoustic walls, namely mixing materials with the composition of marble powder polyurethane 10\%: 90\%, 20\%: 80\%, 30\%: 70; 40\%: 60\%, 50\%; 50\% and 60\%: $40 \%$.

3. Preparing the materials and testing equipment, including the test specimen, impedance tube, and microphone.

4. Testing the acoustic wall in two ways, namely measuring the initial intensity (I0) without using materials and measuring the final intensity (I) with different sample concentrations.

5. Perform data analysis by calculating the sound absorption coefficient value.

6. This research's expected output is the publication of articles in international journals, monograph books, and simple patents.

\section{Result and Discussion}

\section{A. Specimen}

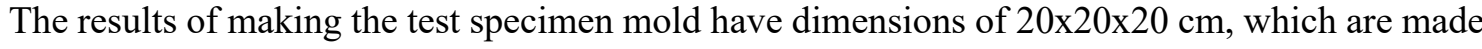
of plywood and iron plate with a size of $2 \mathrm{~mm}$, as shown in Figure 5 below.

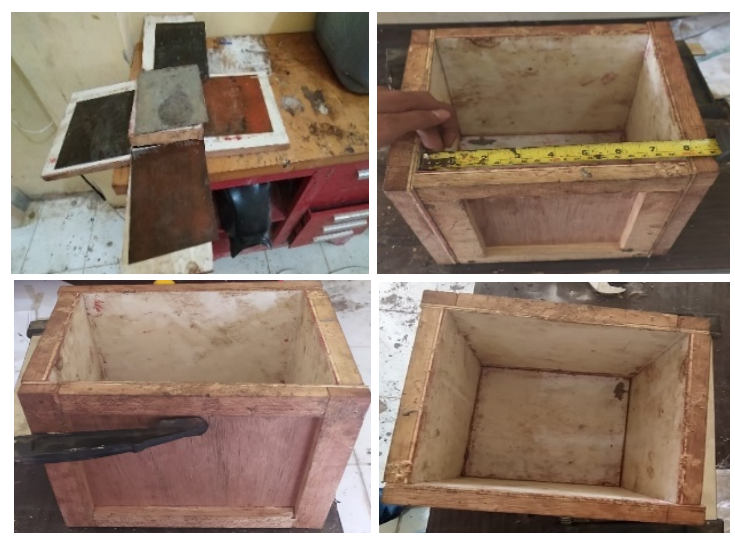

Figure 5. Cast

In the process of measuring the material and stirring the test specimens, the steps taken are measuring and stirring the test specimen material according to the predetermined composition by measuring the compositions using a scale, measuring cup, and mixing the composition of marblepolyurethane-resin powder 10\%: 90\%, 20\%: $80 \%, 30 \%: 70 ; 40 \%: 60 \%, 50 \% ; 50 \%$ and $60 \%: 40 \%$ done in several times, and stirring using a mixer. Then the mixture is poured into the specimen mold and ready to dry in the sun to dry. So the specimen that has been removed from the mold dries and expands. The process of activities and the results of the test specimens can be seen in Figure 6 below. 


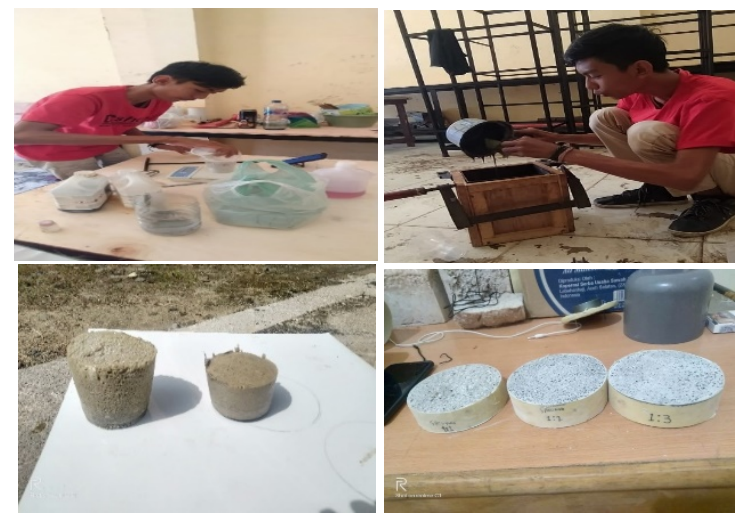

Figure 6. Spesimen

\section{B. Specimen Testing}

Specimens made with variations in the mass composition of marble powder and polyurethane 1: 1, 1:2, and 1: 3 with a thickness of $5 \mathrm{~cm}, 3 \mathrm{~cm}$, and $1 \mathrm{~cm}$ form an excellent and hollow material. The test with a two-microphone impedance tube has a limit of $125 \mathrm{~Hz}-4000 \mathrm{~Hz}$. The difference in the sound absorption coefficient of a material is influence by the material's thickness and ability to absorb sound at a particular frequency.

\section{Test Results of 1: 1 Test Specimens}

The test results on a 1:1 composition specimen with three thickness variations are as shown in Table 2 .

Table 2. Sound Absorption Results 1: 1 Composition Material

\begin{tabular}{ccccccccccc}
\hline \multirow{2}{*}{ NO } & \multirow{2}{*}{ Frequency $(\mathbf{H z})$} & \multicolumn{3}{c}{$\mathbf{1 ~ c m}$} & \multicolumn{3}{c}{$\mathbf{3 ~ c m}$} & \multicolumn{3}{c}{$\mathbf{5} \mathbf{~ m}$} \\
\cline { 3 - 11 } & $\mathbf{C 1}$ & $\mathbf{C 2}$ & $\boldsymbol{\alpha}$ & $\mathbf{C 1}$ & $\mathbf{C 2}$ & $\boldsymbol{\alpha}$ & $\mathbf{C 1}$ & $\mathbf{C 2}$ & $\boldsymbol{\alpha}$ \\
\hline 1 & 125 & 115.2 & 96.8 & 0.29 & 112.9 & 75.6 & 0.55 & 113.4 & 58.4 & 0.73 \\
2 & 250 & 115.7 & 92.6 & 0.36 & 115.4 & 77 & 0.55 & 115.4 & 61.4 & 0.72 \\
3 & 500 & 111.8 & 101.9 & 0.17 & 112.6 & 89 & 0.38 & 101.2 & 64.2 & 0.60 \\
4 & 1000 & 111.4 & 89.5 & 0.35 & 115.7 & 76.4 & 0.56 & 113.9 & 66 & 0.66 \\
5 & 2000 & 97.6 & 83.5 & 0.27 & 108.4 & 81.2 & 0.44 & 89.7 & 77 & 0.26 \\
6 & 4000 & 108.8 & 103 & 0.10 & 106.1 & 91.4 & 0.26 & 98.4 & 73.9 & 0.44 \\
\hline
\end{tabular}

Table 2.shows the test results on specimens with a ratio of 1: 1 polyurethane and marble powder, so the sound absorption coefficient values are obtained with a thickness of $1 \mathrm{~cm}, 3 \mathrm{~cm}$, and $5 \mathrm{~cm}$ displayed in graphic form as shown in Figure 7.



Figure 7. Graph of 1: 1 Material Sound Absorption Coefficient with a thickness of $1 \mathrm{~cm}, 3 \mathrm{~cm}$, 
Figure 7. explains that the thicker the material, the higher the sound absorption coefficient value. The lowest sound absorption coefficient value was $0.100 .73 \mathrm{~cm}-1$ at a thickness of $1 \mathrm{~cm}$ at a frequency of $4000 \mathrm{~Hz}$, and the highest was $0.73 \mathrm{~cm}-1$ at a thickness of $125 \mathrm{~Hz}$ at a thickness of $5 \mathrm{~cm}$. When viewed on each material, the best sound absorption coefficient is average at a frequency of $500 \mathrm{~Hz}$.

\section{Test Results of 1: 2 Test Specimens}

The test results on specimens of 1: 2 composition with three thickness variations are shown in Table 3.

Table 3. Results of 1: 2 Composition Material Sound Absorption

\begin{tabular}{ccccccccccc}
\hline \multirow{2}{*}{ No } & \multirow{2}{*}{ Frequency (Hz) } & \multicolumn{3}{c}{$\mathbf{1 ~ c m}$} & \multicolumn{3}{c}{$\mathbf{3} \mathbf{~ c m}$} & \multicolumn{3}{c}{$\mathbf{5} \mathbf{~ c m}$} \\
\cline { 3 - 11 } & & $\mathbf{C 1}$ & $\mathbf{C 2}$ & $\boldsymbol{\alpha}$ & $\mathbf{C 1}$ & $\mathbf{C 2}$ & $\boldsymbol{\alpha}$ & $\mathbf{C 1}$ & $\mathbf{C 2}$ & $\boldsymbol{\alpha}$ \\
\hline 1 & 125 & 114.4 & 81.1 & 0.50 & 112.3 & 68.9 & 0.62 & 111 & 66.5 & 0.64 \\
2 & 250 & 115.7 & 81.9 & 0.50 & 115.2 & 69.6 & 0.63 & 114.8 & 65.5 & 0.67 \\
3 & 500 & 110.7 & 90 & 0.34 & 105.5 & 81.5 & 0.40 & 112.1 & 71.4 & 0.59 \\
4 & 1000 & 114.2 & 79.9 & 0.51 & 116.3 & 76.7 & 0.57 & 115.2 & 72.4 & 0.61 \\
5 & 2000 & 110.4 & 84.9 & 0.41 & 109.6 & 83.5 & 0.42 & 107.6 & 88.8 & 0.32 \\
6 & 4000 & 103.1 & 85 & 0.32 & 108.7 & 81.9 & 0.43 & 102.1 & 85.8 & 0.29 \\
\hline
\end{tabular}

Table 3 shows the test results on specimens with a ratio of 1: 2 polyurethane and marble powder, so the sound absorption coefficient values obtained with a thickness of $1 \mathrm{~cm}, 3 \mathrm{~cm}$, and $5 \mathrm{~cm}$ are displayed in graphic form as shown in Figure 8.

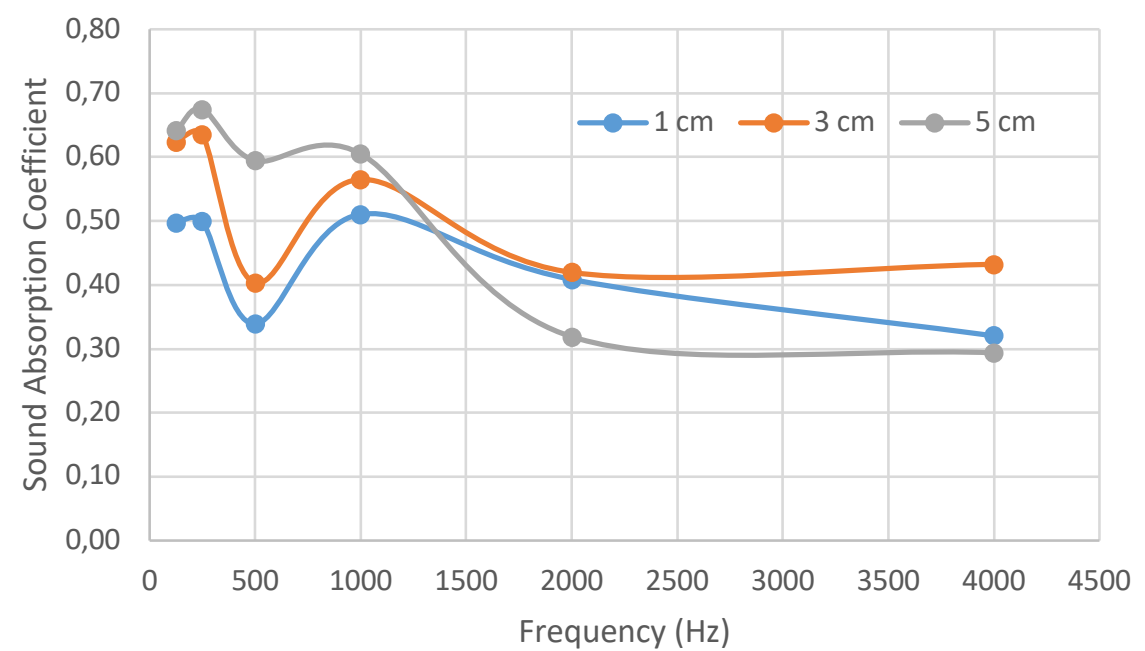

Figure 8. Graph of 1: 2 Material Sound Absorption Coefficient with a thickness of $1 \mathrm{~cm}, 3 \mathrm{~cm}$,

Figure 13. explains that the thicker the material, the higher the sound absorption coefficient value. The lowest sound absorption coefficient value was $0.29 \mathrm{~cm}-1$ at a thickness of $5 \mathrm{~cm}$ at a frequency of $4000 \mathrm{~Hz}$, and the highest was $0.67 \mathrm{~cm}-1$ at a thickness of $5 \mathrm{~cm}$ at $250 \mathrm{~Hz}$. When viewed on each material, the best sound absorption coefficient is average at a frequency of $500 \mathrm{~Hz}$.

\section{E. Test Results of 1: 3 Test Specimens}

The test results on a 1: 3 composition specimen with three thickness variations are shown in Table 4. 
Table 4. Results of 1: 2 Composition Material Sound Absorption

\begin{tabular}{ccccccccccc}
\hline \multirow{2}{*}{ NO } & \multirow{2}{*}{ Frequency $(\mathbf{H z})$} & \multicolumn{3}{c}{$\mathbf{~ c m}$} & \multicolumn{3}{c}{$\mathbf{3 ~ c m}$} & \multicolumn{3}{c}{$\mathbf{5} \mathbf{~ c m}$} \\
\cline { 3 - 11 } & & $\mathbf{C 1}$ & $\mathbf{C 2}$ & $\boldsymbol{\alpha}$ & $\mathbf{C 1}$ & $\mathbf{C 2}$ & $\boldsymbol{\alpha}$ & $\mathbf{C 1}$ & $\mathbf{C 2}$ & $\boldsymbol{\alpha}$ \\
\hline 1 & 125 & 114.1 & 77.3 & 0.54 & 113.2 & 65.2 & 0.67 & 113.1 & 62.3 & 0.70 \\
2 & 250 & 115.7 & 78.8 & 0.54 & 115.4 & 66.9 & 0.66 & 114.7 & 61.6 & 0.71 \\
3 & 500 & 112 & 86.6 & 0.40 & 104.6 & 78.4 & 0.44 & 108.1 & 76.8 & 0.50 \\
4 & 1000 & 114.3 & 78.3 & 0.53 & 116.2 & 70.8 & 0.63 & 114.5 & 72.8 & 0.60 \\
5 & 2000 & 109.7 & 80.3 & 0.46 & 109.9 & 80.3 & 0.47 & 97.6 & 79.9 & 0.33 \\
6 & 4000 & 102.4 & 89 & 0.24 & 111.2 & 83.1 & 0.44 & 102.3 & 75.5 & 0.46 \\
\hline
\end{tabular}

Table 4 shows the test results on specimens with a ratio of $1: 3$ polyurethane and marble powder, so the sound absorption coefficient values obtained with a thickness of $1 \mathrm{~cm}, 3 \mathrm{~cm}$, and $5 \mathrm{~cm}$ are displayed in graphic form as shown in Figure 9.

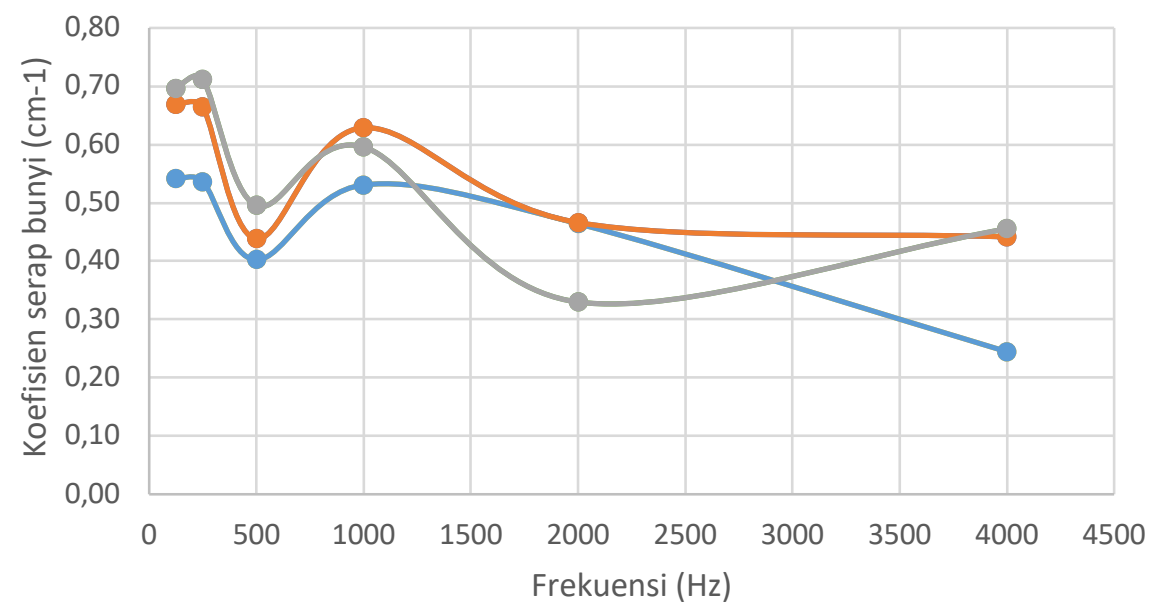

Figure 9. Graph of 1: 3 Sound Absorption Coefficient with a thickness of $1 \mathrm{~cm}, 3 \mathrm{~cm}$, and $5 \mathrm{~cm}$

Figure 9. explains that the thicker the material, the higher the sound absorption coefficient value. The difference in sound absorption coefficient with different thicknesses is not too far away. This proves that the 1:3 material has a high density compared to the amount of foam. The lowest sound absorption coefficient value was 0.24 at a thickness of $1 \mathrm{~cm}$ at a frequency of $4000 \mathrm{~Hz}$, and the highest was 0.71 at a thickness of $5 \mathrm{~cm}$ at a frequency of $250 \mathrm{~Hz}$. When viewed on each material, the best sound absorption coefficient is average at a frequency of $500 \mathrm{~Hz}$.

\section{F. Comparison of Sound Absorption Coefficient Values}

The comparison of the sound absorption coefficient values with the same composition and thickness can be seen in the graph below, which is shown in Figure 10. 


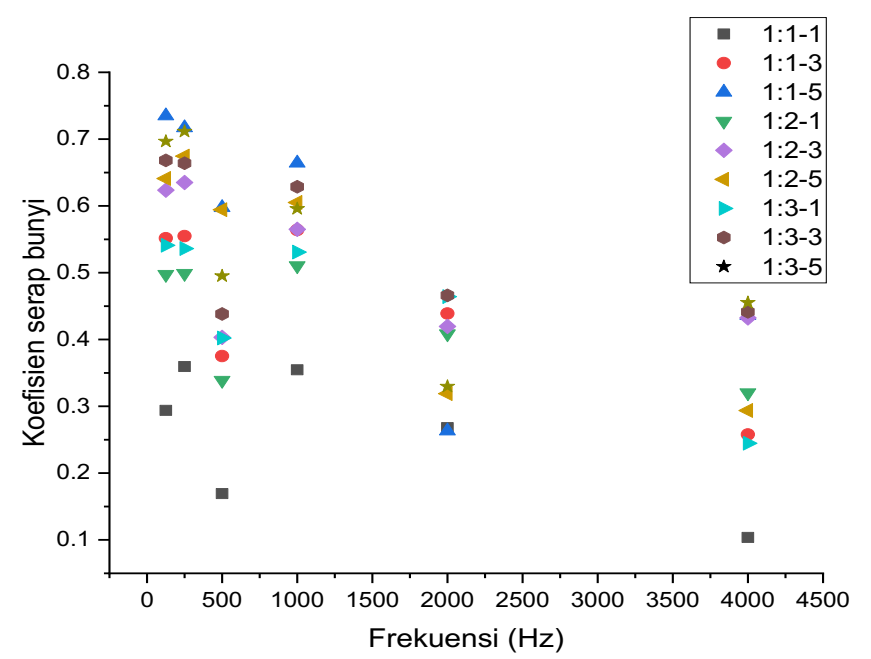

Figure 10. Graph of Material Sound Absorption Coefficient

From Figure 10. Explain that materials with a composition ratio of polyurethane and marble powder 1: 1, 1:2, and 1:3 on average have the same character in terms of sound absorbers where the highest sound absorption coefficient value in each material composition is obtained at low frequencies and vice versa, the lowest sound absorption coefficient at high frequencies. The highest value on average is at a frequency between $125 \mathrm{~Hz}, 250 \mathrm{~Hz}$, and $1000 \mathrm{~Hz}$, and there is always a decrease in the $500 \mathrm{~Hz}$ frequency. If seen in Figure 10, the lowest and highest sound absorption coefficient values are in the 1: 1 specimen with a thickness of $1 \mathrm{~cm}$ and $5 \mathrm{~cm}$. However, in 1:2 and 1: 3 materials, the sound absorption coefficient values are in between. From the graph, it can be explained that the thickness of the material greatly affects the value of the sound absorption coefficient. Thus it can be concluded that the polyurethane composite material mixed with marble powder can be used as a sound-absorbing panel material, especially in a 1: 1 composition.

\section{Conclusions}

From the results of making acoustic wall molds, the process of measuring and stirring the specimen composition, testing the specimen material to analyzing the sound absorption coefficient, several conclusions can be drawn as follows:

1. The test results of 1: 1 test specimens with a thickness of $1 \mathrm{~cm}, 3 \mathrm{~cm}$, and $5 \mathrm{~cm}$ indicate that the lowest sound absorption coefficient value is $0.100 .73 \mathrm{~cm}-1$ at a thickness of $1 \mathrm{~cm}$ at a frequency of $4000 \mathrm{~Hz}$ and the highest is $0.73 \mathrm{~cm}-1$ at a frequency of $125 \mathrm{~Hz}$ at a thickness of $5 \mathrm{~cm}$. When viewed on each material, the best sound absorption coefficient is on average at a frequency of $500 \mathrm{~Hz}$.

2. The test results of the $1: 2$ test specimen with a thickness of $1 \mathrm{~cm}, 3 \mathrm{~cm}$ and $5 \mathrm{~cm}$ indicate that the lowest sound absorption coefficient value is $0.29 \mathrm{~cm}-1$ at a thickness of $5 \mathrm{~cm}$ at a frequency of $4000 \mathrm{~Hz}$ and the highest is $0.67 \mathrm{~cm}-1$ at $5 \mathrm{~cm}$ thickness at $250 \mathrm{~Hz}$. When viewed on each material, the best sound absorption coefficient is on average at a frequency of $500 \mathrm{~Hz}$.

3. The test results of the $1: 3$ test specimen with a thickness of $1 \mathrm{~cm}, 3 \mathrm{~cm}$ and $5 \mathrm{~cm}$ indicate that the lowest sound absorption coefficient value is 0.24 at a thickness of $1 \mathrm{~cm}$ at a frequency of $4000 \mathrm{~Hz}$ and the highest is 0.71 at a thickness of $5 \mathrm{~cm}$ at a frequency of $250 \mathrm{~Hz}$. When viewed on each material, the best sound absorption coefficient is on average at a frequency of $500 \mathrm{~Hz}$.

4. The results of the comparison of the sound absorption coefficient values based on the composition and thickness show that the highest value on average is at a frequency between 125 $\mathrm{Hz}, 250 \mathrm{~Hz}$ and $1000 \mathrm{~Hz}$, and there is always a decrease in the $500 \mathrm{~Hz}$ frequency, so that the lowest and highest sound absorption coefficient values are found. In the 1: 1 specimen with a thickness of $1 \mathrm{~cm}$ and $5 \mathrm{~cm}$. However, in 1:2 and 1:3 materials, the sound absorption coefficient value is in between.

5. The highest sound absorption coefficient value for each material composition is obtained at low frequencies and vice versa, the lowest sound absorption coefficient at high frequencies, on the 
grounds that the thicker the material, the higher the sound absorption coefficient value, thus it can be concluded that the polyurethane composite material is mixed with marble powder. Can be used as sound-absorbing panel material, especially in 1:1 compositions.

\section{Acknowledgment}

Our gratitude goes to the Directorate of Research and Community Service, Directorate General of Research and Development Strengthening of the Ministry of Research, Technology and Higher Education, LLDIKTI Region XIII Aceh, LPPM Polytechnic South Aceh, the research team who has facilitated and helped until the completion of this research. Henceforth, researchers will carry out the improvement and development of this research with the materials and composition of the test specimens that are more different than what has been done so that they can find a superior composite material with a higher sound absorption coefficient value and can be used for sound-absorbing materials.

\section{Reference}

[1] L. Lindawati and M. Mursal, "XRD Analysis of Mineral Composition in Marble from Gunung Kerambil, South Aceh,” J. Inotera, vol. 3, no. 2, pp. 65-69, 2018.

[2] I. Ihsan and N. Fitriadi, "Composite Materials Characteristic Analysis of Marble Waste And Resin With Bending Test," J. Inotera, vol. 3, no. 2, pp. 93-97, 2018.

[3] N. Fitriadi, L. Lindawati, and I. Ardiansyah, Mechanical Properties of Hybrid Marble Powder and Kenaf Fibre Reinforced Polyester Resin Composites, vol. 506. 2019.

[4] A. Luiz Guilherme Meira de Souza, Natanaeyfle Randemberg Santos and L. C. F. C. Gonçalves Cavalcante, Luiz Guilherme Vieira Meira de Souza, "Composite utilizing residues of marble and granite for building popular,” J. Build. Eng., vol. 9, pp. 192-197, 2017.

[5] G. Sung and J. H. Kim, "Influence of filler surface characteristics on morphological, physical, acoustic properties of polyurethane composite foams filled with inorganic fillers," Compos. Sci. Technol., vol. 146, pp. 147-154, 2017.

[6] G. Soto et al., "Biobased porous acoustical absorbers made from polyurethane and waste tire particles," Polym. Test., vol. 57, pp. 42-51, 2017.

[7] Dewi, Adella Kusmala dan Elvaswer."Material Akustik Serat Pelepah Pisang (Musa acuminax balbasiana calla) Sebagai Pengendali Potensi Bunyi". Jurnal Fisika Unand Vol. 3, no. 1 (2015): h. 78-82.

[8] S. Salimi et al., "Property enhancement of healable supramolecular polyurethanes," Eur. Polym. J., vol. 118, pp. 88-96, 2019.

[9] Arlindo Rizal, dkk, 2015, "Karakteristik Absorbsi Dan Impedansi Material Akustik Serat Alam Ampas Tahu (Glycine Max) Menggunakan Metode Tabung"Jurnal Ilmu Fisika (JIF). Vol.7. No.1. Maret 2015. E-ISSN : $1979-4657$.

[10] Riko Wahyudin Kosar, dkk, 2018, "Analisa kemampuan Meredam Suara Pada Batu Bata Komposit Berbahan Semen, Pasir Faba (Fly Ash Bottom Ash)"Enthalpy-Jurnal Ilmiah Mahasiswa Teknik Mesin. Vol.3. No.4. Desember 2018. E- ISSN : $2502-8944$. 